William E. Ackerman MD, Mushtaque M. Juneja MD, David M. Kaczorowski Do, George W. Colclough MD* $^{*}$

\section{A comparison of the incidence of pruritus following epidural opioid administration in the parturient}

The traditional method of providing postoperative analgesia is with intramuscular opioids. However, epidural opioids have become increasingly popular. Morphine is currently the most widely used epidural opioid for postoperative pain control. Epidural morphine produces excellent analgesia but the incidence of pruritus is high following administration in the patient after Caesarean section. ${ }^{1}$ Furthermore, epidural morphine has been reported to be associated with reactivation of the herpes simplex virus labialis (HSVL) in the post-Caesarean section population. ${ }^{2,3}$ The mechanism of viral reactivation is unknown but may be caused by a skin trigger mechanism (i.e., scratching). ${ }^{2}$ In addition to morphine, three other epidural opioids (fentanyl, buprenorphine and butorphanol) have all been reported to be effective in the management of pain after Caesarean section. ${ }^{4-6}$ However, we are unaware of any study which compared the incidence of pruritus among these drugs. This doubleblind prospective study compared the incidence of pruritus associated with epidural morphine, fentanyl, buprenorphine, or butorphanol administered to post-Caesarean section-patients.

\section{Methods}

Institutional Review Board approval and informed consent from each patient in this study were obtained. Sixty ASA physical status I or II patients who had requested epidural anaesthesia and were scheduled for elective Caesarean section were studied for the incidence of pruritus following epidural opioid administration. The patients were randomly assigned to one of four groups each consisting of 15 patients. All patients were prehydrated with $15 \mathrm{ml} \cdot \mathrm{kg}^{-1}$ IV lactated Ringer's solution prior to establishment of the epidural block. All epidural needles were placed at the $\mathrm{L}_{2-3}$ or $\mathrm{L}_{3-4}$ interspaces using a loss of resistance technique with air and each epidural catheter was advanced $2-3 \mathrm{~cm}$ into the epidural space. All epidural catheter placements were done with the patient in the sitting position. Preoperative medication consisted only of $30 \mathrm{ml}$ of sodium citrate. Patients were excluded 
from the study if they had a history of pruritus within one week of surgery, had taken antihistamines or steroids within one week of surgery, had urticaria within one week of surgery, or had a previous history of HSVL.

Each patient was placed in a left lateral supine position on the operating table after the epidural catheter was placed. All patients received oxygen by nasal cannulac at $3 \mathrm{~L} \cdot \min ^{-1}$. The blood pressure, respiratory rate, skin temperature, oxygen saturation and ECG were monitored. All patients received 0.5 per cent bupivacaine without epinephrine in incremental doses until at least a $T_{4}$ sensory level to pinprick was obtained. Immediately after clamping the umbilical cord, each patient received, in a double-blind fashion, one of the four study solutions through the epidural catheter at an infusion rate of 2 $\mathrm{ml} \cdot \mathrm{min}^{-1}$.

Group I: Received $5 \mathrm{mg}(10 \mathrm{ml})$ epidural preservativefree morphine.

Group II: Received fentanyl, $50 \mu \mathrm{g}(1 \mathrm{ml})$ diluted with $9 \mathrm{ml}$ of preservative-free saline.

Group III: Received buprenorphine, $0.3 \mathrm{mg}(1 \mathrm{ml})$ diluted with $9 \mathrm{ml}$ of preservative-free saline.

Group IV: Received butorphanol, $1 \mathrm{mg}(1 \mathrm{ml})$ diluted with $9 \mathrm{ml}$ of preservative-free saline.

The patients were questioned at 1, 3, 12 and 24 hours by a blinded independent observer for the incidence of pruritus. All patients were included in the study until they requested analgesia for postoperative pain. The duration of analgesia was defined as the time of study drug administration until the patient expressed any pain (a score greater than 0 on a 0 - 10 verbal response scale). Pruritus was scored $0-1(0=$ none; $1=$ mild to moderate, requiring no treatment; $2=$ severe, requiring treatment). Pruritus was treated with $25 \mathrm{mg}$ diphenhydramine IM or $0.1-0.2 \mathrm{mg}$ naloxone if pruritus was severe. All interval data were analyzed for normalcy of distribution using a Shapiro-Wilk W statistic. Depending upon the results of this analysis, intergroup responses were compared using either a parametric or nonparametric one-way analysis of variance followed by the appropriate critical value test for multiple comparisons. The complex chi square contingency table was used to analyze qualitative data. A P value of 0.05 was considered to be the minimal level of statistical significance.

\section{Results}

There were no maternal differences among the four groups (Table I). There were no differences in the volume of bupivacaine administered or in the duration of surgery (Table II). Groups I (morphine) and II (fentanyl) exhibited statistically significant more pruritus when compared with Groups III (buprenorphine) and IV (butorphanol) (Table III). The duration of analgesia was significantly
TABLE I Matemal differences

\begin{tabular}{llll}
\hline Group & Age (yrs) & Height $(\mathrm{cm})$ & Weight $(\mathrm{kg})$ \\
\hline Morphine & $22.8 \pm 1.9$ & $162.9 \pm 6.2$ & $76.2 \pm 7.7$ \\
Fentanyl & $23.1 \pm 2.3$ & $162 \pm 6.6$ & $75.8 \pm 7.9$ \\
Buprenorphine & $23.3 \pm 2.5$ & $163.1 \pm 6.0$ & $76.6 \pm 8.0$ \\
Butorphanol & $23.1 \pm 2.8$ & $164 \pm 6.4$ & $75.3 \pm 7.6$ \\
\hline
\end{tabular}

Values are means $=\mathrm{SD}$. $\mathrm{n}=15$.

There were no significant differences between groups.

TABLE II Operative characteristics

\begin{tabular}{|c|c|c|c|}
\hline Group & $\begin{array}{l}\text { Total dose } \\
\text { of } 0.5 \% \\
\text { bupivacaine (ml) }\end{array}$ & $\begin{array}{l}\text { Duration } \\
\text { of surgery (min) }\end{array}$ & $\begin{array}{l}\text { Duration of } \\
\text { surgery from } \\
\text { time of study } \\
\text { solution } \\
\text { administration } \\
\text { (min) }\end{array}$ \\
\hline Morphine & $22.91 \pm 2.1$ & $64.73 \pm 5.97$ & $24.13 \pm 1.8$ \\
\hline Fentanyl & $24.2 \pm 1.89$ & $63.93 \pm 6.85$ & $24.2 \pm 1.9$ \\
\hline Buprenorphine & $23.87 \pm 1.8$ & $63.21 \pm 3.9$ & $23.87 \pm 1.8$ \\
\hline Butorphanol & $23.67 \pm 1$ & $66.47 \pm 4.1$ & $23.97 \pm 2.0$ \\
\hline
\end{tabular}

Values are means $\pm S D$

There were no significant differences between groups.

TABLE III Incidence of pruritus

\begin{tabular}{llll}
\hline Group & Incidence & Percent & $\begin{array}{l}\text { Duration } \\
\text { of analgesia (min) }\end{array}$ \\
\hline Morphine & $9 / 15$ & 60 & $931.95 \pm 87.4$ \\
Fentanyl & $7 / 15$ & 46.7 & $145 \pm 38.2$ \\
Buprenorphine & $0 / 15^{*}$ & 0 & $388.06 \pm 54.6$ \\
Butorphanol & $1 / 15$ & 6.7 & $96.71 \pm 23.2^{*}$ \\
\hline
\end{tabular}

$* \mathrm{P}<0.05$

The incidence of pruritus was significantly less with bupnenorphine and butorphanol. The duration of analgesia was significantly longer with morphine when compared with each of the other groups.

longer in the morphine group when compared with each of the other three groups (Table III). Pruritus was severe, requiring treatment in eight patients ( 88.9 per cent) who had pruritus in the morphine group and five patients (71.4 per cent) in the fentanyl group. Diphenhydramine alone was efficacious in relieving pruritus in three patients ( 37.5 per cent) in the morphine group and two ( 40 per cent) in the fentanyl group. The remaining patients who complained of pruritus required naloxone treatment. The patient in the butorphanol group did not require treatment for pruritus.

\section{Discussion}

One of the advantages of epidural opioids is that the duration of analgesia is usually longer than that obtained from equal doses of parenteral opioids. Three opioid 
receptors (mu, kappa, and delta) exhibit antinociceptive mechanisms when activated by drugs administered on the surface of the spinal cord. The mu and kappa receptors are both effective in modulating afferent mechanical and chemical noxious stimuli at the spinal cord level, while delta receptors appear to be most effective against thermal stimuli. ${ }^{8}$ Morphine and fentanyl, both agonist opioids, have a high affinity for mu receptors. ${ }^{8,9}$ Butorphanol, a mixed agonist-antagonist opioid, has a higher affinity for kappa than for mu receptors. ${ }^{9}$ Buprenorphine, which is a partial opioid agonist, possesses a high affinity for mu receptors with low kappa receptor affinity. ${ }^{10}$ However, buprenorphine is reported to stimulate a small percentage of kappa receptors. "I

Central nervous system opiate receptors are thought to be involved in the perception of pruritus because the opiate antagonist naloxone has been reported to reverse the pruritus evoked by epidural morphine and because plasma histamine levels are not elevated following epidural morphine administration. ${ }^{12,13}$ The observation that diphenhydramine relieved pruritus in some patients in both the morphine and fentanyl groups suggests that there may be more than one aetiology of pruritus following epidural opioid administration. Our results demonstrated that the opioids that stimulated kappa receptors following epidural administration exhibited significantly less pruritus than pure mu receptor opioids administered in a similar fashion. Furthermore, Naulty et al. reported that the addition of butorphanol to fentanyl administered epidurally to patients after Caesarean section significantly decreased the incidence of pruritus compared with fentan$\mathrm{yl}$ alone. ${ }^{14}$ The reason for the decreased incidence of pruritus following the epidural administration of mixed receptor opioids is unknown but may be related to kappa receptor stimulation.

Of the synthetic opioids studied, epidural buprenorphine provided the longest duration of analgesia with no pruritus following a single injection. It is uncertain whether or not scratching the skin can cause an HSVL infection. ${ }^{2}$ Furthermore, we are unaware of any studies which associate other epidural opioids with reactivation of HSVL. However, at present, we believe one should attempt to minimize the incidence of pruritus in any patient with a history of HSVL. Herpes simplex encephalitis is an uncommon disease but it can be associated with severe morbidity and high mortality. ${ }^{15}$ Most often it results from reactivation of the HSVL virus.

In this study, we reported that epidural buprenorphine administration was not associated with pruritus. Other authors, however, have reported mild pruritus with an incidence not significantly different from a control group following epidural buprenorphine in the postoperative patients. ${ }^{16}$ Gieraerts et al. reported that patients who received IM morphine and who had a positive history of HSVL did not report a recurrence of the disease postoperatively. ${ }^{3}$ In the post-Caesarean section patient with a history of recurrent herpes simplex virus labialis, a more conventional method of providing analgesia might be considered an alternative to epidural narcotics for postoperative pain control until further information is available on the association of HSVL reactivation and epidural opioids.

\section{References}

1 Kotelko DM, Dailey PA, Shnider SM, Rosen MA, Hughes SC, Brizgys RV. Epidural morphine analgesia after cesarean delivery. Obstet Gynecol 1984; 63: 409-13.

2 Crone LAL, Conly JM, Clark KM et al. Recurrent herpes simplex virus labialis and the use of epidural morphine in obstetric patients. Anesth Analg 1988; 67: 318-23.

3 Gieraerts $R$, Navalgund $A$, Vaes $L$, Soetens $M$, Chang $J L$, $J a h r T$. Increased incidence of itching and herpes simplex in patients given epidural morphine after cesarean section. Anesth Analg 1987; 1321-4.

4 Naulty IS, Weintraub SJ, McMahon J, Ostheimer GW, Hunt $C$, Chantigian $R$. Epidural butorphanol for post cesarean delivery pain management. Anesthesiology 1984; 61: A415.

5 Ackerman WE, Juneja MM, Colclough GW. A comparison of epidural fentanyl, buprenorphine and butorphanol for the management of post cesarean section pain. Anesthesiology 1988; 69: A401.

6 Naulty JS, Datta S, Ostheimer GW, Johnson MD, Burger $G A$. Epidural fentanyl for post cesarean delivery pain management. Anesthesiology 1985; 63: 694-8.

7 Douglas JM, McMorland GH, Janzen JA. Influence of bupivacaine as an adjuvant to epidural morphine for analgesia after cesarean section. Anesth Analg 1988; 67: 1138-41.

8 Neil A, Terenius $L$. Receptor mechanisms for nociception. In International Anesthesiology Clinics, Sjostrand UH, Rawal N (Eds.), Little, Brown, \& Co, Boston 1986; 24: 1-15.

9 Iwamoto ET, Martin WR. Multiple opioid receptors. Medicinal Research Reviews 1981; 1: 411-40.

10 Villiger $J W$. Binding of buprenorphine to opiate receptors. Regulation by quanyl nucleotides and metal ions. Neuropharmacology 1984; 23: 373-9.

11 Lewis JW. Pharmacological profile of buprenorphine and its clinical use in cancer pain. In: Foley KM, Inturisi CE: Advances in Pain Research and Therapy, Vol 8, Raven Press, New York, 1980; 268. 
12 Korsch J, Ramanathan S, Parker F, Turndorf H. Systemic histamine relief by epidural morphine. Anesthesiology 1987; 67: A445.

13 Dailey PA, Brookside GL, Snider SM et al. Naloxone decreases side effects after intrathecal morphine for labor. Anesth Anal 1984; 64: 658-66.

14 Naulty IS, LaBove P, Datta S, Hunt CO, Ostheimer GW. Epidural butorphanol/fentanyl for post-Cesarean delivery analgesia. Anesthesiology 1987; 67: A462.

15 Price $R W$. Acute viral meningitis and encephalitis. $I n$. Wyngaarden JB, Smith LH. Cecil's Textbook of Medicine, W.B. Saunders, Philadelphia, 1988; 2193.

16 Lanz E, Simko G. Theiss D, Glocke ME. Epidural buprenorphine. A double blind study of postoperative analgesia and side effects. Anesth Analg 1984; 63: 593-8.

\section{Résumé}

Après une césarienne, l'analgésie à la morphine par voie péridurale est souvent associée d̀ du prurit. Dans une étude à double insu chez 60 patientes en santé, nous avons comparé la morphine, le fentanyl, la buprénorphine et le butorphanol quant à l'incidence de cette complication lorsque injecté par voie péridurale lors d' une césarienne. On recherchait la présence de prurit à 1, 3, 12 et 24 h post-injection. Le problème s'est avéré plus fréquent avec la morphine et le fentanyl. Malheureusement, malgré une faible incidence de prurit, la durée de l'analgésie avec la buprénorphine ou le butorphanol était insuffisante en mode d'injection unique. 